\title{
Faktor Lingkungan yang Mendorong Perilaku Warga Lereng Merapi untuk Tidak Mengungsi
}

\author{
S. Andarwati, F.T. Haryadi, T.M. Widi, N.D. Dono \\ Fakultas Peternakan Universitas Gadjah Mada, Yogyakarta
}

\begin{abstract}
ABSTRAK
Fenomena gunung Merapi yang merupakan gunung api tipe Strato paling aktif di Indonesia menarik untuk dipelajari. Terjadi beberapa kali letusan yang mengancam tidak hanya jiwa manusia tetapi harta benda. Kenyatan di lapangan, banyak warga lereng Merapi yang tidak mengungsi pada saat Merapi menunjukkan peningkatan aktivitas. Penelitian ini bertujuan untuk mengetahui faktor lingkungan yang mendorong perilaku warga lereng Merapi untuk tidak mengungsi. Metode dasar yang digunakan dalam penelitian ini adalah deskriptif analisis. Pengambilan data dilakukan dengan cara survey, pemilihan responden melalui metode purposive random sampling. Hasil penelitian menggambarkan bahwa faktor lingkungan yang mendorong warga lereng Merapi untuk tidak mengungsi disebabkan oleh : 1) Adanya upaya mempertahankan aset ekonomi sebagai sumber penghasilan utama, dalam hal ini adalah ternak sapi perah dikarenakan belum ada kandang pengungsian yang memadai untuk ternak sapi perah, 2) Pengalaman masa lalu ialah belum pernah terjadi adanya korban jiwa dan harta benda yang terjadi di desa mereka, 3) Keyakinan masyarakat setempat yang telah turun temurun bahwa wilayah mereka berada di daerah yang aman (di muka/halaman gunung Merapi).
\end{abstract}

Kata kunci : Lingkungan, Merapi, mengungsi, ternak

\section{Environment Factor That Motivated People on Merapi Slope Not to Flee}

\begin{abstract}
Phenomenon of Merapi Mountain that the most active Strato mountain in Indonesia was interest to learn. There many explosion were threat of danger, not only human but include with property. Fact, there many people in the dangerous Merapi area were not escape from the area when Merapi showed raising activity. The research conduct to determine environment factors were motivated people on Merapi slope not to flee. The method used by descriptive analysis, data were taken with survey, the respondent of survey taken by purposive random sampling method. The result showed that: 1) Effort to defend economics asset as the main source of family income, dairy cattle in the case, because of there's no good evacuation stable for cattle, 2) Experiences of the past, there were none human killed or property loss in their village and 3) People's believe for generation that his area was not in dangerous because it stand in front of the mountain; were motivated people on Merapi slope not to flee.
\end{abstract}

Key words : Environment, Merapi, flee, animal 


\section{PENDAHULUAN}

Berdasar sumber informasi dari Balai Penyelidikan dan Pengembangan Teknologi Kegunungapian (BPPTK) Yogyakarta diperoleh informasi bahwa gunung api Merapi merupakan gunung api aktif yang dipadati penduduk dengan berbagai macam aktivitasnya, salah satu diantaranya adalah usaha peternakan sapi perah. Kawasan lereng Merapi meliputi 14 desa di kecamatan Turi, Pakem dan Cangkringan. Sepanjang tahun 2002-2003 peternakan sapi perah di Sleman rata-rata menghasilkan 1,7 juta liter susu dari total produksi susu rakyat DIY sebanyak 1,82 juta liter pertahun. Populasi sapi perah di Sleman 7.971 ekor, sekitar 88\% (7.062) tersebar di kecamatan Turi, Pakem dan Cangkringan (Kompas, 2007). Terjadi beberapa kendala di lapangan antara lain sulitnya mengevakuasi warga di daerah bencana.

Psikologi memandang perilaku manusia (human behavior) sebagai reaksi yang dapat bersifat sederhana maupun bersifat kompleks. Fenomena sikap tidak saja ditentukan oleh keadaan objek yang sedang kita hadapi tetapi juga oleh pengalaman-pengalaman masa lalu, situasi saat sekarang dan oleh harapan-harapan kita untuk masa yang akan datang. Pada manusia khususnya terdapat bentuk-bentuk perilaku instinktif (spesies spesific bahavior) yang didasari oleh kodrat mempertahankan kehidupan (Azwar, 2005).

Salah satu karakteristik perilaku manusia adalah sifat diferensialnya. Maksudnya satu stimulus dapat menimbulkan lebih dari satu respon yang berbeda dan beberapa stimulus yang berbeda dapat saja menimbulkan satu respon stimulus yang sama.

Kurt Lewin (1951) dalam Brigham (1991) merumuskan suatu model hubungan perilaku yang mengatakan bahwa perilaku/behavior (B) adalah fungsi karakteristik individu (P) dan lingkungan/environment (E), dirumuskan :

$$
\mathrm{B}=f(\mathrm{P}, \mathrm{E})
$$

Keterangan:

B : Behavior (Perilaku)

P : Performan (Karakter individu)

E : Environment (Lingkungan)

Selanjutnya dinyatakan oleh Brigham (1991) bahwa karakteristik individu meliputi berbagai variabel seperti motif, nilai-nilai, sifat kepribadian dan sikap saling berinteraksi satu sama lain dan kemudian berinteraksi pula dengan faktor-faktor lingkungan dalam menentukan perilaku. Faktor lingkungan memiliki kekuatan besar dalam menentukan perilaku bahkan kadang-kadang kekuatannya lebih besar dari karakteristik individu. Hal ini menjadikan prediksi perilaku lebih kompleks.

Ajzen (1988) mengemukakan Teori Tindakan Beralasan (Theory of reasoned action) yang didasarkan pada asumsi-asumsi a) bahwa manusia umumnya melakukan sesuatu dengan cara-cara yang masuk akal, b) bahwa manusia mempertimbangkan semua informasi yang ada, dan c) bahwa secara eksplisif maupun implisif manusia memperhitungkan implikasi tindakan mereka. Teori Tindakan Beralasan mengatakan bahwa sikap perilaku manusia dipengaruhi lewat suatu proses pengambilan keputusan yang teliti dan beralasan dan dampaknya terbatas pada tiga hal yaitu 1) perilaku tidak banyak ditentukan oleh sikap umum tapi oleh sikap yang spesifik terhadap sesuatu, 2) perilaku dipengaruhi tidak hanya oleh sikap tetapi norma-norma subyektif (Subjective norm) yaitu keyakinan kita mengenai apa yang orang lain inginkan agar kita perbuat, dan 3) sikap terhadap suatu perilaku bersama norma-norma subjektif membentuk suatu intensi atau niat untuk berperilaku tertentu.

Berdasar hal tersebut, dilakukan penelitian ini untuk mengetahui faktor lingkungan yang mendorong perilaku warga lereng Merapi untuk tidak mengungsi. 
Tabel 1. Populasi sapi perah di daerah rawan bencana Merapi

\begin{tabular}{clc}
\hline No & \multicolumn{1}{c}{ Dusun } & Sapi perah (Ekor) \\
\hline 1 & Tunggularum, Wonokerto & 60 \\
2 & Ngandong dan Tritis, Girikerto & 254 \\
3 & Turgo I \& II, Purwobinangun & 300 \\
4 & Pangukrejo, Umbulharjo & 154 \\
5 & Pelemsari/Kinahrejo, Umbulharjo & 169 \\
6 & Ngrangkah, Umbulharjo & 305 \\
7 & Kalitengah Lor \& Kalitengah Kidul, Glagahharjo & 400 \\
8 & Kaliadem, Kepuharjo & 600 \\
\hline & Jumlah & 2.242 \\
\hline
\end{tabular}

Sumber : Dinas Pertanian Propinsi DIY, (2006).

\section{MATERI DAN METODE}

Materi yang digunakan dalam penelitian ini meliputi 60 responden penduduk sekitar lereng Merapi yang termasuk dalam daerah rawan bencana. Dusun Kaliadem, desa Kepuharjo dipilih dengan pertimbangan memiliki populasi sapi perah terbanyak dan merupakan desa terdekat dengan puncak Merapi/kawasan rawan bencana III (Anonim, 2007). Responden merupakan warga yang menetap di lokasi tersebut sejak sebelum Mei 2006 dengan dasar pemikiran bahwa responden pernah mengalami sedikitnya satu kali dalam perjalanan hidupnya menghadapi bahaya letusan dan erupsi dari gunung Merapi dan memelihara ternak sapi perah pada saat bencana erupsi Merapi pada bulan Mei 2006.

Penelitian dilakukan dengan metode deskriptif analisis, ialah metode pengumpulan data dan fakta yang ada untuk membahas masalah-masalah aktual yang dihadapi masyarakat saat ini. Tahapan pelaksanaan meliputi observasi dan perijinan, pencatatan dan survey dengan wawancara langsung melibatkan responden yang dipilih. Metode pengambilan sampel dilakukan dengan menggunakan metode purposive random sampling (Singarimbun dan Effendi, 1995).

\section{Batasan operasional}

Mengungsi diartikan sebagai "pergi menyelamatkan diri ketempat yang dirasa aman selama 24 jam perhari pada waktu yang ditentukan oleh pemerintah yang berwenang. Waktu 24 jam dimaksudkan karena ancaman bahaya letusan Merapi tidak dapat diprediksi, sehingga sewaktu-waktu dapat terjadi, baik pada siang ataupun malam hari.

\section{HASIL DAN PEMBAHASAN}

\section{Karakteristik Responden}

Karakteristik responden berupa jenis kelamin, pendidikan, statis kependudukan dan jenis pekerjaan pokok dapat diamati dalam tabel 2 .

\section{Jenis kelamin}

Jenis kelamin laki-laki menempati $88,33 \%$ dan perempuan $11,67 \%$. Keadaan ini menggambarkan bahwa peternakan sapi perah pada umumnya diusahakan bersama-sama oleh laki-laki dan perempuan, dalam hal ini dilakukan oleh suami dan istri. Perbedaan nilai persentase diatas bukan berarti jumlah laki-laki yang mengusahakan lebih banyak dari perempuan, akan tetapi semata-mata menunjukkan bahwa pada saat survey dan wawancara dilakukan lebih banyak bertemu/ bertanya kepada laki-laki sebagai kepala keluarga.

\section{Pendidikan}

Peternak sapi perah sebesar $75 \%$ belum menyelesaikan pendidikan formal setingkat Sains Peternakan Vol.8 (1), Maret 2010 
Tabel 2. Karakteristik responden

\begin{tabular}{lrc}
\hline \multicolumn{1}{c}{ Keterangan } & Jumlah & Persentase \\
\hline Jenis kelamin : & & \\
a. Laki-laki & 53 & 88,33 \\
b. Perempuan & 7 & 11,67 \\
Pendidikan : & 7 & 11,67 \\
a. Tidak sekolah & 38 & 63,33 \\
b. SD & 10 & 16,67 \\
c. SMP & 3 & 5,00 \\
d. SMA & 2 & 3,33 \\
e. D2/ D3 & & \\
Status Kependudukan : & 52 & 86,67 \\
a. Asli & 8 & 13,33 \\
b. Pendatang & & \\
Pekerjaan pokok : & 100 & 100,00 \\
a. Peternak & 0 & 0,00 \\
b. Swasta &
\end{tabular}

Sumber : Analisis data primer, (2008).

SLTP atau belum menyelesaikan masa wajib belajar sembilan tahun, hal ini menunjukkan bahwa tingkat pendidikan responden masih rendah. Pendidikan merupakan salah satu indikator penting mengenai produktivitas peternak, dengan pendidikan kita bisa melihat seberapa besar kualitas sumber daya peternak karena dengan pendidikan tinggi diharapkan dapat merubah pola pikir maupun pola hidup peternak yang tadinya kurang rasional menjadi rasional. Bagi peternak, pendidikan yang tinggi diperlukan untuk bekal dalam mengelola usahataninya agar lebih efektif dan efisien.

\section{Status kependudukan}

Status kependudukan peternak menunjukkan bahwa $86,67 \%$ merupakan penduduk asli setempat sedangkan sisanya merupakan pendatang. Kondisi ini menunjukkan bahwa usaha ini banyak diminati oleh penduduk lokal. Keadaan tersebut sangat baik khususnya bagi pengembangan sumber daya dan kegiatan ekonomi lokal dalam mendukung otonomi daerah. Dalam pelaksanaan pembangunan era otonomi daerah sekarang ini, diharapkan pemerintah dan masyarakat mampu memanfaatkan potensi yang sesuai dengan wilayah masing-masing.

\section{Pekerjaan}

Sejumlah 60 responden atau 100\% responden memiliki pekerjaan pokok sebagai peternak, hal ini berarti bahwa peternakan sapi perah dipandang sebagai suatu usaha yang dianggap mampu untuk mencukupi kebutuhan hidup, dengan perkataan lain sebagian besar responden mengganggap beternak sapi perah dapat diandalkan sebagai tumpuan dan sumber pendapatan utama bagi keluarga mereka.

Responden selain memiliki pekerjaan pokok sebagai peternak sapi perah, sebagian diantaranya memiliki pekerjaan sampingan sebagai penggali/pencari pasir, buruh, karyawan, mengelola penginapan, pencari kayu dan pembuat arang.

\section{Umur}

Rata-rata umur responden 46,90 tahun dengan distribusi umur seperti pada Tabel 4.

Umur merupakan salah satu indikator produktifitas kerja peternak karena berhubungan dengan tingkat kemampuan fisik peternak dalam mengelola usahanya. Penduduk berumur $\leq 15$ masuk dalam kategori belum produktif karena masih dalam usia sekolah. 
Umur 16-55 termasuk dalam usia produktif,

Tabel 3. Pekerjaan sampingan responden

\begin{tabular}{lcc}
\hline \multicolumn{1}{c}{ Keterangan } & Jumlah & Persentase \\
\hline Penggali/pencari pasir & 8 & 13,33 \\
Buruh & 7 & 11,67 \\
Karyawan & 5 & 8,33 \\
Mengelola penginapan & 1 & 1,67 \\
Pencari kayu & 1 & 1,67 \\
Pembuat arang & 1 & 1,67 \\
Tidak memiliki pekerjaan sampingan & 37 & 61,67 \\
\hline
\end{tabular}

Sumber: Analisis data primer, (2008).

Tabel 4. Distribusi umur responden

\begin{tabular}{ccc}
\hline Kelompok umur (tahun) & Jumlah (orang) & Persentase (\%) \\
\hline$\leq 15$ & 0 & 0,00 \\
$16-55$ & 44 & 73,33 \\
$\geq 56$ & 16 & 26,67 \\
\hline
\end{tabular}

Sumber : Analisis data primer, (2008).

sedangkan penduduk berumur $\geq 56$ masuk dalam kategori tidak produktif karena pada usia tersebut merupakan masa pensiun dimana kemampuan fisik seseorang sudah mengalami banyak penurunan. Pada penelitian ini sejumlah $73,33 \%$ peternak berumur pada kisaran $16-55$ tahun yang termasuk dalam kategori usia produktif sehingga diharapkan akan mampu bekerja secara maksimal dan memungkinkan menerima informasi dan inovasi baru terkait usaha ternak dan pencegahan bencana.

\section{Jumlah tanggungan keluarga}

Jumlah tanggungan keluarga mencerminkan beban bagi suatu rumah tangga karena kepala rumah tangga harus mampu memenuhi segala kebutuhan meliputi pangan, sandang, papan dan sebagainya. Oleh karena itu kepala rumah tangga akan berupaya untuk memperoleh penghasilan agar kebutuhan rumah tangganya terpenuhi.

Anggota keluarga selain sebagai tanggunggan/beban ternyata mempunyai sisi positip yaitu apabila mereka termasuk dalam usia produktif, sehingga bisa dijadikan sebagai tenaga kerja keluarga yang dapat membantu baik dalam pekerjaan rumah tangga maupun tatalaksana pemeliharaan sapi perah.

Hasil penelitian menunjukkan bahwa rata-rata jumlah anggota keluarga sejumlah 4,10 orang. Diharapkan dengan banyaknya anggota keluarga mampu menekan jumlah pengeluaran untuk membayar tenaga kerja karena sebagian dari pekerjaan dapat diselesaikan oleh tenaga kerja yang berasal dari dalam keluarga.

\section{Lama domisili}

Lama domisili seseorang dapat berpengaruh positip terhadap pengalaman hidup dan ketrampilan dalam bermasyarakat dan adaptasi dengan lingkungan alam sekitar. Peternak dengan pengalaman cukup cenderung dapat mengatasai masalah-masalah yang timbul dalam pelaksanaan usaha dan mampu menggunakan alternatif pemecahan masalah yang efisien sehingga mampu menghasilkan keuntungan usaha yang maksimal. Terkait dengan bencana alam Merapi, mereka telah memiliki kebiasaan yang diadopsi secara turun 
Tabel 5. Distribusi lama domisili

\begin{tabular}{ccc}
\hline Kelompok umur (tahun) & Jumlah (orang) & Persentase $(\%)$ \\
\hline$\leq 2$ & 0 & 0,00 \\
$2-6$ & 0 & 0,00 \\
$\geq 11$ & 60 & 100,00 \\
\hline
\end{tabular}

Sumber : Analisis data primer

Tabel 6. Rata-rata pemilikan ternak

\begin{tabular}{lc}
\hline \multicolumn{1}{c}{ Jenis ternak } & Jumlah (ekor/peternak) \\
\hline Sapi Perah & 3,38 \\
Kambing & 0,05 \\
Ayam Buras & 10,60 \\
\hline
\end{tabular}

Sumber : Analisis data primer, (2008).

Hasil penelitian menunjukkan bahwa 60 responden atau $100 \%$ peternak termasuk sudah cukup lama berdomisili di lokasi penelitian (dusun Kaliadem) yaitu diatas 15 tahun, dengan rata-rata lama tinggal 43,82 tahun, artinya mereka telah beberapa kali mengalami bencana Merapi setidaknya minimal 3 kali yaitu pada tahun 2006, 2001 dan 1997.

\section{Kepemilikan Ternak}

Peternak memelihara sapi perah sebagai ternak pokok dan memelihara ayam buras sebagai sampingan, satu diantara peternak memelihara kambing. Kepemilikan ternak dapat diamati dalam tabel 6 .

Induk laktasi menempati jumlah terbesar dengan rata-rata pemilikan 1,23 ekor/peternak. Hal ini berarti peternak memelihara sapi perah dengan tujuan utama untuk menghasilkan susu. Pedet menempati urutan kedua. Pada umumnya peternak menjual pedet sebagai salah satu pendapatan, sebagian diantaranya dipelihara sendiri untuk peremajaan induk. Secara terperinci, kepemilikan ternak sapi perah dapat diamati pada tabel 7 .

\section{Perilaku mengungsi warga}

Responden yang merupakan warga lereng Merapi semuanya tidak mengungsi pada saat Merapi menunjukkan peningkatan aktivitas. Sebesar 57 orang (95\%) melakukan proses mobilitas turn over atau aktivitas pulang balik yaitu pagi sampai sore hari tetap berada di lokasi bencana, sedangkan malam hari bermalam di barak pengungsian.

Mayoritas warga lereng Merapi laki-laki yang masih dalam kategori usia produktif atau mampu bekerja, memilih tetap bertahan dirumah pada pagi-sore hari, sedangkan wanita, lansia dan anak-anak diungsikan ke barak pengungsian. Faktor-faktor yang mendorong mereka memilih untuk tidak mengungsi antara lain tidak adanya penanganan yang baik untuk tempat evakuasi ternak. Barak pengungsian yang permanen hanya tersedia bagi manusia, sedangkan untuk ternak belum disediakan. Penduduk lebih memilih tidak mengevakuasi ternak mereka karena kandang penampungan sementara dianggap tidak memadai dan peternak kesulitan dalam penyediaan hijauan makanan ternak. Kondisi tersebut dapat dipahami karena peternak biasanya memperoleh hijauan pakan yang berasal dari lahan sendiri atau lahan umum di sekitar lokasi pemukiman. Artinya mereka tidak perlu 
membeli atau mengeluarkan uang untuk pakan, selain pada bulan-bulan tertentu saat kemarau

Rasionalitas warga lereng Merapi menyikapi teknis pengungsian bagi ternak mereka yang merupakan sumber penghasilan tersebut sesuai dengan pendapat Ajzen (1988) dalam Teori Tindakan Beralasan (Theory of reasoned action) yang didasarkan pada asumsiasumsi a) bahwa manusia umumnya melakukan sesuatu dengan cara-cara yang masuk akal, b) bahwa manusia mempertimbangkan semua informasi yang ada, dan c) bahwa secara eksplisif maupun implisif manusia memperhitungkan implikasi tindakan mereka.

Perilaku warga lereng Merapi untuk tidak mengungsi dipengaruhi juga oleh pengalaman masa lalu ialah belum pernah terjadi adanya korban jiwa dan harta benda yang terjadi di desa mereka. Pengalaman masa lalu tersebut diperkuat oleh adanya keyakinan masyarakat setempat yang menganggap desanya tepat berada di muka/halaman gunung panjang, dimana pakan yang tersedia belum mencukupi kebutuhan ternak.

Merapi, sehingga jika sewaktu-waktu Merapi meletus, tidak akan mengenai desa mereka. Letusan Merapi dianggap oleh masyarakat setempat "baru memiliki hajatan", dan menurut keyakinan mereka, orang yang punya hajatan tidak akan membuang sampah di depan rumah. Kepercayaan ini melahirkan sikap sebagian besar warga lereng Merapi yang beranggapan bahwa Merapi bukan merupakan ancaman bagi mereka (tabel 9).

Hal ini sesuai dengan pendapat (Azwar, 2005) yang menyatakan bahwa fenomena sikap tidak saja ditentukan oleh keadaan objek yang sedang kita hadapi tapi juga oleh pengalamanpengalaman masa lalu, situasi saat sekarang dan oleh harapan-harapan kita untuk masa yang akan datang. Pada manusia khususnya terdapat bentuk-bentuk perilaku instinktif (spesies spesific bahavior) yang didasari oleh kodrat mempertahankan kehidupan.

Tabel 7. Rata-rata pemilikan sapi perah

\begin{tabular}{lc}
\hline \multicolumn{1}{c}{ Jenis } & Jumlah (ekor/peternak) \\
\hline Pejantan & 0,33 \\
Induk Bunting & 0,42 \\
Induk Laktasi & 1,23 \\
Induk Kering & 0,13 \\
Dara & 0,35 \\
Pedet & 0,92 \\
\hline
\end{tabular}

Sumber: Analisis data primer, (2008). 
Tabel 8. Persentase warga lereng Merapi yang mengungsi

\begin{tabular}{ccc}
\hline Keterangan & Jumlah (orang) & Persentase (\%) \\
\hline Mengungsi pada pagi-sore hari & 57 & 95 \\
Tidak Mengungsi sama sekali & 3 & 5 \\
\hline
\end{tabular}

Sumber: Analisis data primer, (2008).

Tabel 9. Tanggapan warga terhadap bahaya letusan gunung Merapi

\begin{tabular}{ccc}
\hline Keterangan & Jumlah (orang) & Persentase (\%) \\
\hline Sebagai ancaman & 13 & 21,67 \\
Bukan ancaman & 47 & 78,33 \\
\hline
\end{tabular}

Sumber: Analisis data primer, (2008).

\section{KESIMPULAN}

Faktor lingkungan yang mendorong warga lereng Merapi untuk tidak mengungsi disebabkan oleh :

1. Upaya mempertahankan aset ekonomi sebagai sumber penghasilan utama, dalam hal ini adalah ternak sapi perah dikarenakan belum ada kandang pengungsian yang memadai untuk ternak sapi perah.

2. Pengalaman masa lalu ialah belum pernah terjadi adanya korban jiwa dan harta benda yang terjadi di desa mereka.

3. Keyakinan masyarakat setempat yang telah turun temurun bahwa wilayah mereka berada di daerah yang aman (di muka/halaman gunung Merapi).

\section{DAFTAR PUSTAKA}

Ajzen, I., 1998, Attitudes, Personality and Behavioural, Open University Press. Milton Keynes
Anonim, 2006, Rencana Penanggulangan Bencana Merapi, Dinas Pertanian Propinsi DIY, Yogyakarta.

Anonim, 2006, Laporan Kesiapsiagaan Antisipasi Bahaya Lahar Dingin Kecamatan Cangkringan, Kecamatan Cangkringan, Yogyakarta.

Anonim, 2007, Draft Rencana Kontijensi Penanggulangan Bencana Primer Gunung Merapi, Dinas Pengairan, Pertambangan dan Penanggulangan Bencana Alam (P3BA), Yogyakarta.

Anonim, 2008, www.kompas.com, dikunjungi pada tanggal 23 Februari 2008.

Azwar, S., 2005, Sikap Manusia Teori dan Pengukurannya, Edisi ke-2, Pustaka Pelajar, Yogyakarta.

Brigham, J.C., 1991, Social Psychology, 2nd edition, Harper Collins Publishers Inc., New York.

Singarimbun, M. dan S. Effendi, 1995, Metode Penelitian Survei, LP3ES, Jakarta. 